\title{
Nest site selection by Hypsiboas faber (Anura, Hylidae) in southern Brazil
}

\author{
André L. Luza', Eliane R. da Silva', Daniela M. Failace' \& Patrick Colombo³
}

\begin{abstract}
1.Programa de Pós-Graduação em Ecologia, Universidade Federal do Rio Grande do Sul, Av. Bento Gonçalves 9500, Caixa Postal 15007, $91501-970$ Porto Alegre, RS, Brazil. (luza.andre@gmail.com; anesilva.bio@hotmail.com; dani.failace@yahoo.com.br)

2. Programa de Pós-Graduação em Biologia de Ambientes Aquáticos Continentais, Universidade Federal do Rio Grande, Av. Itália, Km 8, Campus Carreiros, Caixa Postal 474, 96203-900 Rio Grande, RS, Brazil.

3. Setor de Herpetologia/Anfíbios, Seção de Zoologia de Vertebrados, Museu de Ciências Naturais, Fundação Zoobotânica do Rio Grande do Sul, Rua Dr Salvador França, 1427, Jardim Botânico, 90690-000 Porto Alegre, RS, Brazil. (patrick_colombo@hotmail.com, corresponding author)
\end{abstract}

\begin{abstract}
Male gladiator frogs of Hypsiboas Wagler, 1830 build nests on available substrate surrounding ponds and streams where female spawn eggs during the breeding period. Although gladiator frogs seem to show plasticity in the way they construct their nests, there is no study reporting if these species present preferences about microhabitat conditions for nest-building (mainly under subtropical climate). Predation pressure and environmental conditions have been considered major processes shaping the great diversity of reproductive strategies performed by amphibians, but microhabitat conditions should explain where to build a nest as well as how nest looks. This study aimed to test nest site selection for nest-building by Hypsiboas faber (Wied-Neuwied, 1821), determining which factors are related to nest site selection and nest features. The survey was conducted at margins of two permanent ponds in Southern Brazil. Habitat factors were evaluated in 18 plots with nest and 18 plots in the surrounding without nest (control), describing vegetation structure and heterogeneity, and substrate characteristics. Water temperature was measured inside the nest and in its adjacency. Nest features assessed were area, depth and temperature. Habitat characteristics differed between plots with and without nest. Microhabitat selected for nest-building was characterized by great vegetation cover and height, as well as shallower water and lower cover of organic matter in suspension than in plots without nest. Differences between temperature inside nest and in its adjacency were not observed. No relationship between nest features and habitat descriptors was evidenced. Results revealed that Hypsiboas faber does not build nests anywhere. Males seem to prefer more protected habitats, probably avoiding predation, invasion of conspecific males and inclement weather. Lack of differences between temperature inside- and outside-nest suggest that nest do not improve this condition for eggs and tadpole development. Nest architecture was not related to habitat characteristics, which may be determined by other factors, as nest checking by females before amplexus. Nest site selection should increase offspring survival as well the breeding success of Hypsiboas faber.
\end{abstract}

KEYWORDS. Amphibian reproductive modes, Anura life-history, nest-building anurans, nest features, oviposition site.

RESUMO. Seleção de sítio para nidificação de Hypsiboas faber (Anura, Hylidae) no sul do Brasil. Machos de espécies de Hypsiboas Wagler, 1830 constroem ninhos no substrato disponível no entorno de corpos d'água; as fêmeas depositam os ovos no interior destes ninhos durante a reprodução da espécie. Embora estes machos apresentem plasticidade na escolha de sítios para construção dos ninhos, ainda não existem avaliações de preferências por condições específicas de microhabitat para a nidificação (principalmente em clima subtropical). A pressão de predação e as condições ambientais são consideradas os principais processos moldando a diversidade de estratégias reprodutivas em anfíbios. Entretanto, condições de microhábitat deveriam determinar tanto onde construir um ninho quanto as variações na arquitetura do ninho. Neste estudo testamos hipóteses de seleção de microhábitats para a nidificação por sapos-ferreiros Hypsiboas faber (Wied-Neuwied, 1821), determinando características de hábitat relacionados à seleção de sítios e à arquitetura dos ninhos. O estudo foi conduzido nas margens de duas lagoas permanentes no sul do Brasil. Variáveis caracterizando o substrato e a estrutura e heterogeneidade da vegetação foram medidas em 18 parcelas com ninho e 18 parcelas adjacentes sem ninho (controle). A temperatura da água foi medida dentro do ninho e na adjacência. Atributos do ninho foram a área, a profundidade e a temperatura. Resultados demonstraram diferenças nas características de hábitat entre parcelas com e sem ninho. Parcelas com ninhos apresentaram maior cobertura e altura da vegetação, lâmina de água pouca profunda e com pouca matéria orgânica em suspensão em relação às parcelas sem ninho. Não foi observada diferença entre a temperatura dentro e fora do ninho, bem como relação entre os atributos do ninho e os descritores do habitat. Os resultados evidenciaram a seleção de hábitat para a construção de ninhos por Hypsiboas faber. Os machos parecem utilizar habitats mais protegidos, provavelmente para evitar predação, a invasão de machos coespecíficos e a ação de intempéries climáticas. A ausência de diferença entre a temperatura dentro e fora do ninho sugere que o ninho não melhora condições para o desenvolvimento dos ovos e dos girinos. A arquitetura do ninho não teve relação com fatores ambientais; comportamentos como a checagem do ninho pela fêmea antes do amplexo podem estar envolvidos. A seleção de determinados sítios para a construção de ninho deve aumentar a chance de sobrevivência da prole e o sucesso reprodutivo de Hypsiboas faber.

PALAVRAS-CHAVE. Anuros construtores de ninhos, atributos do ninho, história de vida dos anuros, modos reprodutivos de anfíbios, sítio de oviposição.

One of the most remarkable features about life history of amphibians is the variety of ways and habitats in which they reproduce (HADDAD \& PRADO, 2005; WeLls, 2007). Particularly, anurans exhibit diverse reproductive modes mostly shaped by environmental conditions that species are exposed, mainly water availability and temperature (Duellman \& Trueb, 1994; Zug et al., 2001; Haddad \& Prado, 2005; Wells, 2007). In addition to environmental restrictions, one of the most relevant ecological forces shaping reproductive modes and reproductive site selection in anurans is predation pressure (Magnusson \& Hero, 1991; Duellman \& Trueb, 1994). To avoid tadpole mortality due to predation pressure and climatic adversities, many groups became adapted to reproduce in a wide range of habitats such as leaf litter layer and stems or branches of trees at humid forests (e.g. Brachycephalidae), in bromeliad holes (e.g. Dendrobatidae) and in plant leaves (e.g. Centrolenidae) (Duellman \& 
Trueb, 1994; Zug et al., 2001; Haddad \& Prado, 2005). Other species oviposit within subterraneous chambers (e.g. Leptodactylidae) or even carry offsprings on dorsum (e.g. Dendrobatidae) (Wells, 2007).

Males of some Hylidae anurans construct basins or nests in margins of several types of water bodies (reproductive mode 4 - ZUG et al., 2001; HADDAD \& PRADO, 2005); females deposit their eggs as films directly on water of these shallow basins or elliptical nests excavated by males (e.g. Kluge, 1981; Martins, 1993a). This reproductive mode appears in three Hylidae groups (also known as gladiator frogs): Bokermannohyla circumdata (Cope, 1871) group, Hypsiboas faber group and $H$. semilineatus (Spix, 1824) group, implying in independent origins and homoplasy of nest-building behavior in Hylidae (Faivovich et al., 2005). Kluge (1981) suggested that selective pressure imposed by aquatic predators is great enough to determine appearance and maintenance of nestbuilding behavior in the gladiator frog's lineage. Studies about natural history of gladiator frogs have evaluated reproductive and behavioral aspects of the species (KLUGE, 1981; Martins \& Haddad, 1988; Martins, 1993a,b; MARTINs et al., 1993; ForTI \& BerTOLUCCI, 2012; LiMA et al., 2013). All these studies were performed in tropical ecosystems and found plasticity in macrohabitat preferences (e.g. reproduction in temporary and permanent ponds), and lack of associations with climatic conditions (e.g. temperature). However, in subtropical regions - a region subjected to ecological pressure such as cold, frost, seasonality on temperature - a limited number of studies tested how ecological pressures in microhabitat scale affect the reproductive behavior of frog species (e.g. ZANK et al., 2010; HuCKEMBECK et al., 2012); for nest-building gladiator frogs, no study was found.

Male gladiator frogs tend to show plasticity in where to build or to acquire a nest -according to type of substrate locally available (HöBEL, 2008; HARTMANN et al., 2010). Male Hypsiboas faber usually constructs almost circular nests just pushing away aquatic vegetation at pond margins (MARTINS, 1993a), but the species can also use pools in rock outcrops or in pre-existing depressions in sand or mud, or even re-use abandoned nests that they only have to renovate a little (Kluge, 1981; HöBel, 2008). However, decision about where to build/use a nest may be affected by other microhabitat conditions beyond substrate type; microhabitat must be examined and preferences should lead males to select specific sites for nesting. Selection of protected sites seems essential against exposure to predation and harsh environmental conditions (KLUGE, 1981; MARTINs, 1993a). Furthermore, vegetation cover around ponds, for example, may differ in malleability and in protection for males during nest building. Males should choose tall vegetation and spend more time building and improving nests in protected sites, which confer protection to predators and microclimatic stability for tadpole development (KLUGE, 1981). Subtle changes in substrate quality and in vegetation structure between sites - comparing sites where nests are present with sites without nests - may reflect challenges for nest building and even affect nest architecture, leading males to select sites for nesting.

Nest architecture (e.g. size, shape) must differ depending on type of microhabitat and substrate used. Nest size, for instance, is smaller when nests are built on hard substrate than on soft substrate (KLUGE, 1981, Martins, 1993a). Basins built in more suitable and protected sites - which are less affected by rain, floods, wind and by invasion of conspecific males - should be greater (in area and water volume) and maintain a greater number of eggs (Kluge, 1981; Lima et al., 2013; but see Martins, 1993a). Furthermore, these nests should improve conditions for offspring development - comparing with conditions at nest adjacency - which generally require high temperature and high levels of dissolved oxygen in water to avoid hypoxia (Seymour, 1999; Wells, 2007). Therefore, the definition of microhabitat factors chosen for nest establishment - which may reflect nest features - may elucidate which conditions are related to reproductive success and temporal/spatial persistence of nest-building anurans.

This study aimed to test if there is differential selection of microhabitat for nest-building by the gladiator frog Hypsiboas faber, and which specific vegetation and substrate characteristics are mostly selected for nesting. The study also aimed to evaluate if habitat characteristics determine nest temperature and architecture, and if temperature differs inside nest and in its adjacency. For this, nest features were assessed and habitat structure was evaluated in plots with $H$. faber nests and in plots in the surrounding areas without nest. Five hypotheses were tested: (1) males select habitat for nest-building; (2) increases in soil resistance and water depth - i.e. quality of substrate, which can difficult nest-building - show negative association with presence of nests; (3) higher temperature is expected inside nests than in the surrounding area; (4) habitat structure determines nest temperature, area and depth; (5) nests larger, deeper and with higher temperature are mainly related to greater plant cover and height.

\section{MATERIAL AND METHODS}

Model species. The gladiator frog species under study, Hypsiboas faber, has a wide geographic distribution, and it is endemic from South America. The species occurs at southeast Paraguay, northwest Argentina and in Brazil (Lavilla et al., 2010). In Brazil, H. faber distribution seems to follow closely the territory of the Atlantic Rainforest, which is mainly in Brazilian coast (HADDAD et al., 2013). The species also occurs in grasslands of Argentina and South Brazil and in Brazilian Cerrado (savannas), occupying forests, open fields, and also degraded areas (LaVILla et al., 2010). Hypsiboas faber is one of the largest Hylidae, measuring 8.5-10 cm (FAIvovich et al., 2005). MARTINs (1993b) observed that $H$. faber builds nests at margins of ponds and streams during the breeding period 
(spring and summer months); however, the species seems to prefer margins of deep and permanent ponds for nesting (MARTINs, 1993b; IoP et al., 2012). Males construct a nest rotating the body while pushing the substrate out, using their limbs (KLuge, 1981; MARTins, 1993a). In the nest, a small pool of 11-21 cm depth is formed (MARTINS, 1993a), in which males perform advertisement and courtship calling to attract females (MARTINS \& HADDAD, 1988). After nest checking and amplexus, females deposit a surface film of $\sim 1000-2700$ small dark eggs within the pool (MARTINS \& HADDAD, 1988; HARTMANN et al., 2010).

Study area. This study was conducted at Center of Research and Nature Conservation Pró-Mata, São Francisco de Paula municipality - Rio Grande do Sul, Brazil, an area covered by a vegetation mosaic formed by Araucaria Forest, Atlantic Rainforest and Brazilian Upland grasslands (Oliveira \& Pillar, 2004). Pró-Mata $\left(29^{\circ} 26^{\prime} 17^{\prime \prime}\right.$ to $29^{\circ} 43^{\prime} 42^{\prime \prime} \mathrm{S}$ and $50^{\circ} 08^{\prime} 14^{\prime \prime}$ to $50^{\circ} 14^{\prime} 18^{\prime \prime} \mathrm{W}, 600$ to 1,000 $\mathrm{m}$ a.s.1.) has an area of about 3,100 ha. Climate of the region is predominantly Mean Mesothermal Temperate with mean temperature of the coldest month (July) around $10^{\circ} \mathrm{C}$ (IBGE, 2002). Mean precipitation in the region is above 2,000 $\mathrm{mm} \mathrm{yr}^{-1}$ (HiJmans et al., 2005).

Data collection. Data were collected in two permanent ponds in January, 2013. Pond named as "pond 1 " has an area of about $3,000 \mathrm{~m}^{2}$ and the other one named "pond 2" has about $115 \mathrm{~m}^{2}$. In the total, 18 established Hypsiboas faber nests were sampled in the margins of the ponds ( 10 in pond 1 and eight in pond 2). In each nest, habitat descriptors that may offer differential conditions for nest building or even prevent nesting were assessed in a plot ( 1 by $1 \mathrm{~m}$ ) with the nest in the center (Fig. 1). In relation to substrate structure, habitat descriptors measured in each plot were water depth, margin distance, cover of organic material in suspension, and soil resistance. To evaluate soil resistance to nest building, a stone weighting $2.1 \mathrm{~kg}$ was dropped at breast height (1.5 $\mathrm{m}$ high), and depth of the stone-maded hole was measured $(\mathrm{cm})$ with a ruler. Habitat descriptors of vegetation structure were cover of the bryophyte Sphagnum sp. (L.), vegetation height (mean value of five measurements), total vegetation cover, and cover of plant taxonomic groups that were predominant in the ponds. These plant groups were Cyperaceae, Juncaceae, Poaceae, and forbs (herbaceous non-graminoid). Control plots ( 1 by $1 \mathrm{~m}$ - Fig. 1) were established beside plots with nest in order to detect habitat differences between plots with a nest and the available habitat at nest surrounding. For this, a cardinal point was randomly chosen, and then the control plot was disposed $1 \mathrm{~m}$ apart from the nest plot. The same descriptors of substrate and vegetation structure measured on plots with nest were registered in control plots. Thus, 36 plots were evaluated, comprising a paired sampling design (18 plots with nest and 18 plots without nest). Nest features were measured, consisting on nest size (area), nest depth, and water temperature inside nest. In addition, temperature in the adjacency of each nest was measured, using a digital thermometer. All data used for analyses are available in Appendix 1.

Data analysis. The first hypothesis proposed that Hypsiboas faber males select habitat conditions for nestbuilding. To test this hypothesis, plots with nest and control plots were compared according to habitat descriptors. Correlation between variables (habitat descriptors) was evaluated prior to data analyses. When correlation between two variables was greater than 0.6 one of them was removed. Two variables were thus not included in the analyses: margin distance (correlated to Juncaceae cover), and soil resistance (correlated to vegetation cover and organic material in suspension). The relation between plots described by habitat characteristics was first explored by Principal Coordinate Ordination (PCO) based on Gower distance - suitable for variables measured in different scales (LegENDRE \& LEGENDRE, 2012). The PCO results were submitted to bootstrap resampling (1,000 iterations) to verify stability of ordination axes (PILlaR, 1999). To test if plots with and without nest and the two sampled ponds differed according to habitat characteristics -as well as interaction between factors-, a two-way multivariate analysis of variance (MANOVA) with randomization test was performed (factor 1: group - plots with and without nest and factor 2: sampled pond). The two-way MANOVA included a blocking factor (one different level for each pair of plots), in order to control the internal variance of each pair of plots with and without nest. MANOVA statistical test was based on the sum of squares between groups $(\mathrm{Qb}$, Pillar \& Orlóci, 1996). The analysis was ran with 1,000 bootstrap iterations. Gower's similarity index was used as resemblance measure for both PCO and MANOVA. Prior to these analyses, variables were standardized by mean and standard deviation.

To determine which characteristics differed between plots (with nest and available habitat without nest) and between the two sampled ponds, each habitat descriptor was compared between groups using two-way ANOVA with randomization (factor 1: group - with and without nest; factor 2: sampled pond), testing interaction between the factors. The analysis used Bray-Curtis dissimilarity index as resemblance measure and was performed with 1,000 bootstrap iterations. The same analysis was conducted to test for differences between temperature inside nest and in its adjacency. In order to test the relationship between habitat characteristics and nest features, a Mantel correlation test was performed (LEGENDRE \& LEGENDRE, 2012). This analysis aimed to test the correlation (rM) between two matrices of dissimilarity (chord distance between pairs of nests): one containing dissimilarities in nest features and the other characterizing dissimilarities in habitat descriptors. Significance of Mantel correlation was evaluated through permutation test (10,000 iterations). PCO, MANOVA, ANOVA and Mantel analyses were performed using the software Multiv version 3.15 (PILlaR, 2014). 


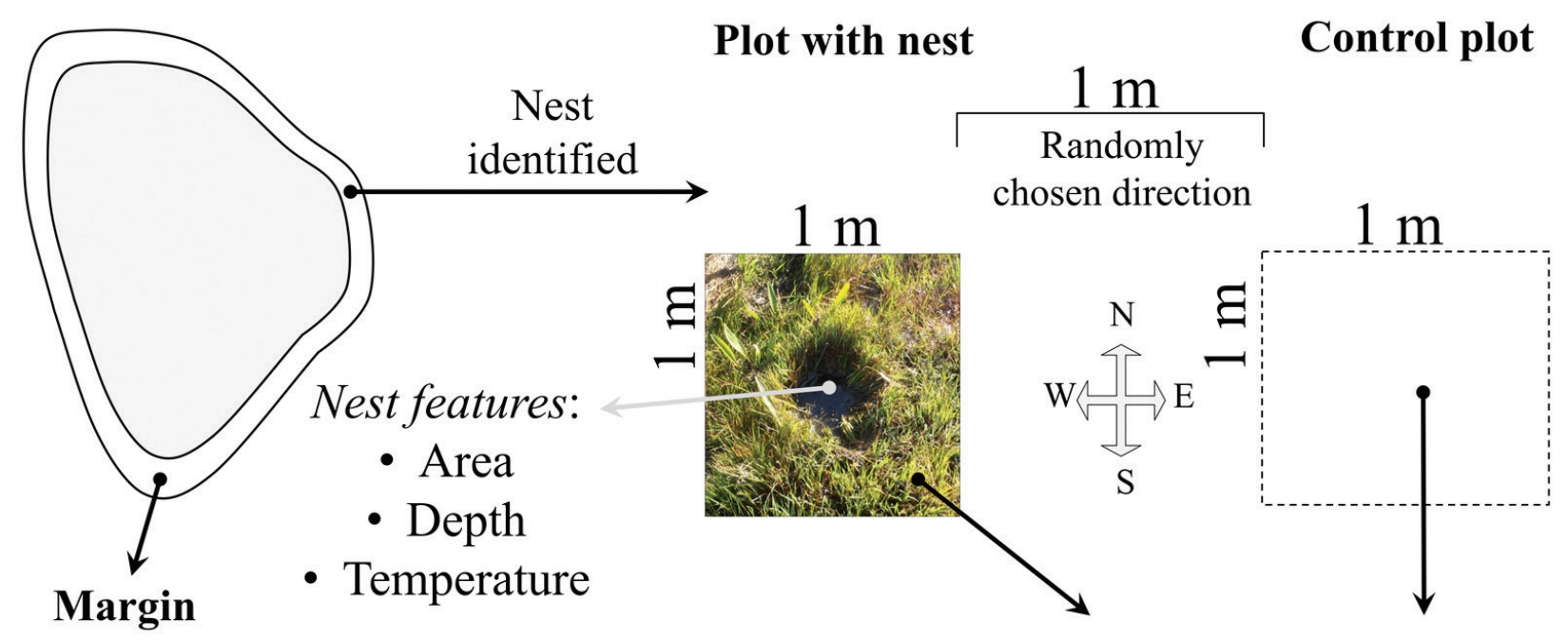

\section{Habitat descriptors: - Vegetation height and cover - Cover by plant taxonomic group - Sphagnum and organic matter cover - Margin distance \\ - Soil resistance - Water depth}

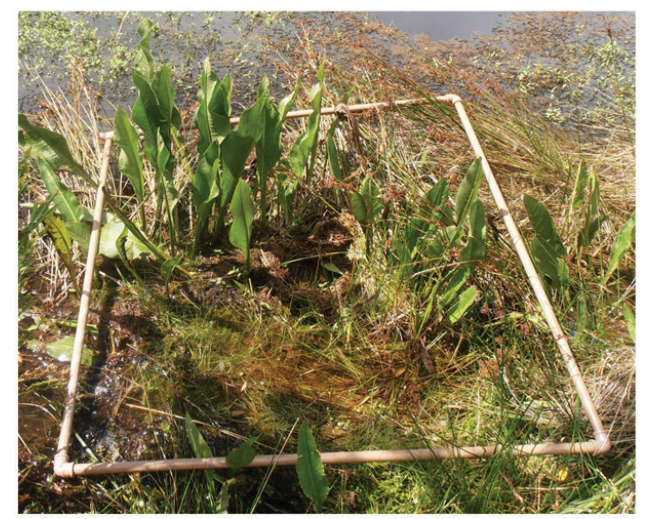

Fig. 1. Schematic drawing of data collection. A paired design was used, consisting of plots with nest of the gladiator frog Hypsiboas faber (WiedNeuwied, 1821) in pond margins and in control plots (without nest). Habitat descriptors and nest features were assessed to test the differential selection of microhabitat for nest-building by the species and the influence of habitat structure in nest features, in Southern Brazil.

\section{RESULTS}

The relation between plots described by habitat descriptors in the PCO demonstrates discrepancies in habitat characteristics between plots with nest of Hypsiboas faber and available habitat (control plots - Fig. 2). This pattern was evident mainly when combining axes I and III, which together explained almost $35 \%$ of total variation in the data, indicating differential use of habitat for nestbuilding; no ordination axis was stable after bootstrap resampling $(\mathrm{p} \leq 0.05)$. The difference in habitat descriptors between groups (with and without nest) was confirmed by MANOVA $(\mathrm{Qb}=0.75 ; \mathrm{p}=0.001)$. Block factor (pair of plots) was marginally significant $(\mathrm{Qb}=4.66 ; \mathrm{p}=0.06)$. There was not difference in habitat conditions between the two sampled ponds $(\mathrm{Qb}=0.71 ; \mathrm{p}=1)$, and a significant interaction between habitat descriptors and the block $(\mathrm{Qb}$ $=3.75 ; p=0.001)$. Without the influence of pair of plots (with blocking factor), differences in habitat descriptors between plots with and without nests remained significant $(\mathrm{Qb}=0.75 ; \mathrm{p}=0.001)$.

In relation to specific differences in each habitat descriptor between plots with and without nest of Hypsiboas faber, it is possible to observe differences for most of the descriptors of substrate and vegetation structure (Tab. I; Fig. 2). Plots with nest presented significantly lower water depth, less organic material in suspension and greater total vegetation cover compared to control plots (Fig. 2). Plant cover in plots with nest consisted of similar proportion of each vegetation type, even though in pond 1 Poaceae represented more than half of plant cover. Cyperaceae cover seemed negatively related to plots with nest (Fig. 2 ), although this descriptor showed greater mean value in plots with nests, mainly in pond 2 (Tab. I). Furthermore, plots with nest were most covered by forbs, Juncaceae and Poaceae, and vegetation height tended to be greater. These trends are better interpreted in the light of differences in these habitat descriptors between ponds (Tab. I). In pond 2, plots with nest had greater Juncaceae cover, lower Poaceae cover, and higher vegetation, with pond 1 showing an inverse pattern. In addition, in pond 2, which had Sphagnum moss in water surface, plots with nest had significantly more cover of this bryophyte than plots without nest.

The 18 evaluated Hyspsiboas faber nests had an area of $456.47 \pm 123.70 \mathrm{~cm}^{3}$ (mean \pm standard deviation) and depth of $10.02 \pm 2.04 \mathrm{~cm}$. Water temperature inside 


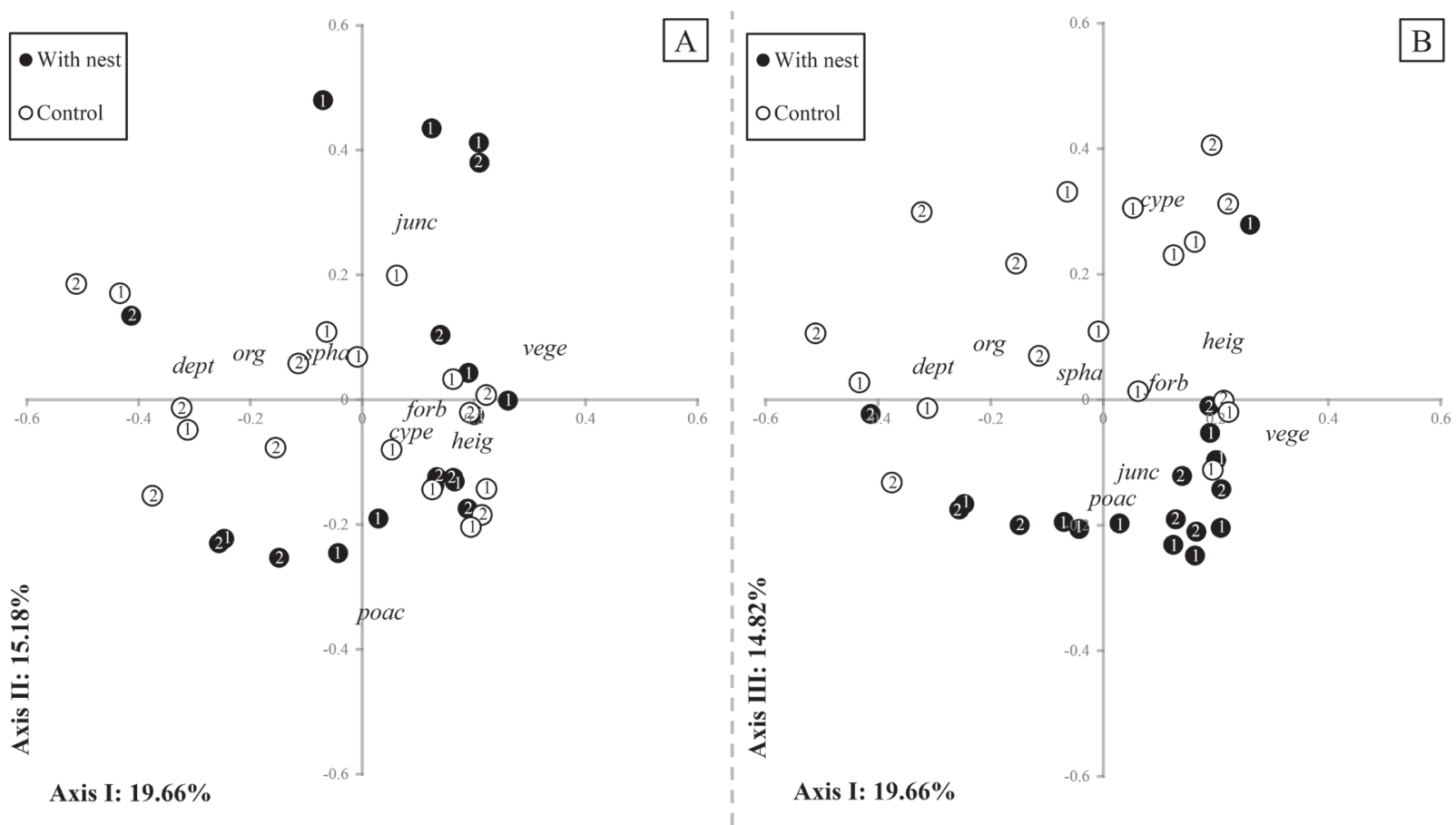

Fig. 2. Ordination diagrams by PCO of plots with and without nest of Hypsiboas faber (Wied-Neuwied, 1821). Gower's index of similarity was used as resemblance measure. The explanation of ordination axes sums $49.66 \%$ of total variation $(19.66,15.18$ and 14.82 for axes 1,2 , and 3 , respectively). A) Axes I and II; B) axes I and III. Habitat descriptors plotted in the diagram were cype $=$ Cyperaceae cover; dept $=$ water depth; forb $=$ forb cover; heig $=$ vegetation height; junc $=$ Juncaceae cover; organic material $=$ org; poac $=$ Poaceae cover; spha $=$ Sphagnum $\mathrm{sp}$. cover; vege $=$ vegetation cover. Number within symbols represents the evaluated ponds (1 and 2).

Tab. I. Descriptors of vegetation and substrate structure in plots with and without nest of Hypsiboas faber (Wied-Neuwied, 1821). Mean values of each habitat descriptor evaluated in plots with nest and controls plots are presented, except by descriptors which showed correlation greater than 0.6 and were previously removed from analysis. Data was collected in two permanent ponds in Southern Brazil. Significant differences are represented by an asterisk, according to two-way ANOVA with randomization testing the interaction between the factors, at $\mathrm{p} \leq 0.05$ level.

\begin{tabular}{|c|c|c|c|c|c|c|c|}
\hline \multirow[b]{2}{*}{ Habitat descriptors } & \multicolumn{2}{|c|}{ Pond 1 group } & \multicolumn{2}{|c|}{ Pond 2 group } & \multicolumn{3}{|c|}{$\mathrm{p}$ value } \\
\hline & $\begin{array}{l}\text { with nest } \\
(\mathrm{n}=10)\end{array}$ & $\begin{array}{l}\text { control } \\
(\mathrm{n}=10)\end{array}$ & $\begin{array}{l}\text { with nest } \\
(\mathrm{n}=8)\end{array}$ & $\begin{array}{l}\text { control } \\
(\mathrm{n}=8)\end{array}$ & group & pond & group $\mathrm{x}$ pond \\
\hline Water depth (cm) & 11.6 & 37.1 & 29.6 & 43.9 & $0.01 *$ & 1 & 0.6 \\
\hline Organic material cover $(\%)$ & 0 & 10 & 3.8 & 19.4 & $0.03 *$ & 1 & $0.008 *$ \\
\hline Vegetation height $(\mathrm{cm})$ & 11.8 & 16.3 & 53.1 & 13.4 & $0.04 *$ & 1 & 0.6 \\
\hline Total vegetation cover $(\%)$ & 87 & 50 & 60 & 43.5 & $0.001 *$ & 1 & 0.7 \\
\hline Poaceae cover $(\%)$ & 62 & 43.6 & 25.5 & 48.8 & $0.03 *$ & 1 & $0.05 *$ \\
\hline Cyperaceae cover $(\%)$ & 10.7 & 6.6 & 22 & 8.5 & $0.002 *$ & 1 & $0.006^{*}$ \\
\hline Juncaceae cover $(\%)$ & 9.5 & 26.4 & 17.5 & 1.3 & 0.06 & 1 & $<0.001^{*}$ \\
\hline Forb cover $(\%)$ & 17.8 & 7.9 & 9.5 & 7.9 & 0.16 & 1 & 0.4 \\
\hline Sphagnum cover $(\%)$ & 0 & 0 & 22 & 5.6 & $0.02 *$ & 1 & $0.008^{*}$ \\
\hline
\end{tabular}

nest was $19.22 \pm 2.04{ }^{\circ} \mathrm{C}$ and in its adjacency it was 18.82 $\pm 1.15^{\circ} \mathrm{C}$, without significant difference $(\mathrm{Qb}=1.48 ; \mathrm{p}$ $=0.447)$. Finally, correlation between dissimilarities in habitat descriptors and nest features (nest area, depth and temperature) was not evident $(\mathrm{rM}=0.19 ; \mathrm{p}=0.12)$.

\section{DISCUSSION}

In this study, an evidence of site selection for nestbuilding by the gladiator frog Hypsiboas faber was shown by the differential preference of some microhabitats among possible choices. This confirms the first hypothesis of this study, and the previous statement of MARTINS \& HADDAD (1988), who suggest non-random selection of microhabitat to construct nests; results also challenge the knowledge that gladiator frogs build nests under any habitat condition. Differential selection of microhabitat for nest-building may reflect advantages for the species in specific conditions, regarding early stage survival and, consequently, increase reproductive success. Males may choose microhabitats that improve stability and maintenance of nest integrity, avoiding predation and disturbances by climatic adversities and conspecific males on early developmental stages. As initially expected, males built their nests in sites with higher vegetation, indicating a preference for more protected sites, as nests should be less visible under high plants or less subjected to desiccation. Also as expected, males built their nests mainly at habitats with greater plant cover and 
shallower water. Habitat preferences seem predominantly related to vegetation structure and not specifically to vegetation type. This was evidenced in plots with nest in which all evaluated plant groups were registered, with variable proportion of each vegetation type cover between the ponds. Moreover, males chose habitats with lower cover of organic matter in suspension, which was negatively correlated with soil resistance and indicates preference for softer substrate.

Spawning in more protected sites may compose a strategy to decrease predation vulnerability of the couple and their offspring, since predation seems an aspect of major importance for oviposition-site choice in many anurans (Magnusson \& Hero, 1991; Refsnider \& JANZEN, 2010). Therefore, predation may be minimized by access to suitable habitats, which provide resources and conditions for which several males may compete during reproduction. A great diversity of predators feed tadpoles within nests (e.g. aquatic insects as Odonate and Hemiptera) or attack froglets and adults in free-water or in the land (e.g. other anurans, snakes, birds and mammals) (KLUGE, 1981; Magnusson \& Hero, 1991; Martins et al., 1993). Proximity with reproduction period and sequential filling of suitable habitats may also force some satellite males to build their nests in suboptimal habitats subjected to high levels of predation and drying of water inside nest (MARTINS \& HADDAD, 1988; MARTINS, 1993a; REFSNIDER \& JANZEN, 2010). Under such conditions, male reproductive success should decrease owing to lower chances of female oviposition in an unprotected nest.

Obtaining access to suitable habitats (e.g. hidden sites with a high percentage of vegetation cover) also minimize external disturbances on water surface film, increasing both couple reproductive success and offspring survival (KLUGE 1981, REFSNIDER \& JANZEN, 2010). Moreover, when nests are built in protected sites, males do not need to renovate them constantly, and can spend more time attracting females or keeping intruders away and taking care for their offspring (KLUGE, 1981; Martins et al., 1998). Nest-care avoid embryo mortality when surface tension of the egg film (in stages 1-18; GOSNER, 1960) is disturbed or broken by other males, and protected sites prevent embryo submersion due to severe rainfall (KLUGE, 1981; Martins \& HadDAD, 1988; Martins et al., 1998). As high energetic investment is necessary for nest-building and nest care, some males can take advantage over other males by minimizing these costs accessing habitats where it is effortless to construct a basin (e.g. soft mud/clay) and easy to monitor it (KLUGE, 1981; Martins et al., 1998).

Rate and duration of tadpole development depend on cumulative temperature and environmental conditions that individuals are subjected (DuelLMAN \& TRUEB, 1994). As pointed by Lamotte \& Lescure in 1977 (mentioned by KLUGE, 1981), temperature within nest would probably be greater than in surrounding water body, which may improve embryonic development. In this study, differences between temperature inside- and outside-nest were not significant. However, there was a subtle trend for higher temperatures inside nest than outside $\left(0.4^{\circ} \mathrm{C}\right.$ in our study and $1.7^{\circ} \mathrm{C}$ in the study of SANABRIA \& QUIROGA (2011); but KLUGE (1981) registered a subtle higher temperature outside nest than inside it $\left(0.4^{\circ} \mathrm{C}\right)$ ). Notwithstanding, differences in water temperature may depend primary on its daily fluctuations and on time of measurement rather than to microclimatic enhancement promoted by nest (KLUGE, 1981), complicating evaluations of nest amelioration for offspring development.

Access to suitable sites - those with greater vegetation height and cover - should cause increases in temperature inside nest and change nest architecture. However, there was no relation between microhabitat descriptors and water temperature in nests, showing that this condition may vary due to other mechanisms, as influx of water and water temperature in surrounding (SEYMOUR, 1999; Mitchell \& Seymour, 2003). In the case of nest architecture, males may be more protected against predators on sites with greater vegetation height and cover, and they could thus spend more time building deeper and larger nests, with more capacity to store eggs and water (MARTINS, 1993a). MARTINS (1993a), for example, observed nests with higher clay/plants ratio were shallower. Nevertheless, results showed no relation between habitat descriptors and nest architecture (depth and area). Nest architecture may be determined by other factors not assessed in this study, as male body size - as hypothesized by MARTINS (1993a) - and behavioral male traits, or even the low number of evaluated nests -18 . However, even with more than twice the number of monitored nests in this study, MarTins (1993a) observed that neither nest water surface nor volume were linked with size of nest-builder males. According to MarTins (1993a), females do not choose males according to body size; frequency of male courtship calling seems more important than body size to attract females (RYAN, 1980). Moreover, female behaviors as careful nest checking before amplexus and spawning may consist in important factors predicting nest architecture (MARTINS \& HADDAD, 1988; MarTins, 1993b).

The main contribution of this study was to refine information concerning site selection for reproduction in gladiator frogs. Hypsiboas faber males were evidenced to select specific sites to build their nests in a wide range of environmental conditions. Access to adequate nest site did not affect nest architecture, which may be determined by other factors, as nest checking by females. Moreover, nests apparently do not ameliorate temperature for eggs and tadpole development. Although direct parameters of reproductive success were not evaluated (i.e. number of surviving tadpoles), decision concerning site selection to build nests and lay eggs can have serious consequences for early stages survival and couple reproductive success. Thus, choice of oviposition-site is a life-history trait of crucial relevance for maintenance of natural populations of gladiator frogs, mainly concerning predation risk and offspring survival. 
Acknowledgements. We thank Dr. Fernando Gertum Becker and M.Sc. Raíssa Furtado Souza (UFRGS) for initial revision of the manuscript and M.Sc. Vinícius Galvão Bastazini for analytical suggestions. We also thank the Coordenação de Aperfeiçoamento de Pessoal de Nível Superior (CAPES) for the M.Sc. scholarships granted to ALL, ERS and DMF, and for a post-doctoral scholarship granted to PC while affiliated at Programa de Pós-Graduação em Biologia de Ambientes Aquáticos Continentais, Universidade Federal do Rio Grande (FURG). We are grateful to the Programa de Pós Graduação em Ecologia of the Universidade Federal do Rio Grande do Sul by supporting field work. We also thank two anonymous reviewers by valuable suggestions on the manuscript.

\section{REFERENCES}

Duellman, W. E. \& Trueb, L. 1994. Biology of amphibians. New York, The John Hopkins University Press, McGraw-Hill Book Company. $670 \mathrm{p}$.

Faivovich, J.; Haddad, C. F. B.; Garcia, P. C. A.; Frost, D. R.; CAmpbell, J. A. \& Wheeler, W. C. 2005. Systematic review of the frog family Hylidae, with special reference to Hylinae: phylogenetic analysis and taxonomic revision. Bulletin of the American Museum of Natural History 294:1-240.

Forti, L. R. \& Bertolucci, J. 2012. Distress call of Hypsiboas faber (Anura: Hylidae) during a Liophis miliaris (Serpentes: Colubridae) attack. Herpetological Notes 5:187-188.

GosNer, K. L. 1960. A simplified table for staging anuran embryos and larvae with notes on identification. Herpetologica 16(3):183-190.

Haddad, C. F. B. \& Prado, C. P. A. 2005. Reproductive modes in frogs and their unexpected diversity in the Atlantic forest of Brazil. BioScience 55(3):207-217.

Haddad, C. F. B.; Toledo, L. F.; Prado, C. P. A.; Loebmann, D.; Gasparini, J. L. \& Sazima, I. 2013. Guia dos Anfíbios da Mata Atlântica: Diversidade e Biologia. São Paulo, Anolisbooks. 544p.

Hartmann, M. T.; Hartmann, P. A. \& Haddad, C. F. B. 2010. Reproductive modes and fecundity of an assemblage of anuran amphibians in the Atlantic Rainforest, Brazil. Iheringia, Série Zoologia 100(3):207-215.

Hijmans, R. J.; Cameron, S. E.; Parra, J. L.; Jones, P. G. \& Jarvis, A. 2005. Very high resolution interpolated climate surfaces for global land areas. International Journal of Climatology 25(15):1965-1978.

HöBEL, G. 2008. Plasticity and geographic variation in the reproductive ecology of gladiator frogs, particularly Hypsiboas rosenbergi. Stapfia 88(80):329-334.

Huckembeck, S.; Claudino, M.; Correa, F.; Bastos, R. F.; Loebmann, D.; TozetTI, A. M. \& Garcia, A. M. 2012. The activity patterns and microhabitat use of Pseudis minuta Günther, 1858 (Anura, Hylidae) in the Lagoa do Peixe National Park, a biosphere reserve of the Brazilian subtropics. Brazilian Journal of Biology 72(2):331-336.

I BGE. 2002. Mapas do Clima do Brasil. Ministério do Planejamento, Orçamento e Gestão. Available at: <ftp://geoftp.ibge.gov.br/mapas tematicos/mapas_murais/clima.pdf $>$. Accessed on: 15 August 2014 .

Iop, S.; Caldart, V. M.; dos Santos, T. G. \& Cechin, S. Z. 2012. What is the role of heterogeneity and spatial autocorrelation of ponds in the organization of frog communities in Southern Brazil? Zoological Studies 51(7): 1094-1104.

KLugE, A. G. 1981. The life history, social organization, and parental behavior of Hyla rosenbergi Boulenger, a nest-building gladiator frog. Miscellaneous Publications, Museum of Zoology, University of Michigan 160:1-170.

Lavilla, E.; Aquino, L.; Kwet, A. \& Baldo, D. 2010. Hypsiboas faber. The IUCN Red List of Threatened Species. Version 2014.2. Available at: <http://www.iucnredlist.org > Accessed on: 29 July 2014.
Legendre, P. \& Legendre, L. 2012. Numerical Ecology. Amsterdam, Elsevier. 990p.

Lima, M. S. C. S; Pederassi, J. \& Souza, C. A. S. 2013. Aspectos ecológicos da reprodução de Hypsiboas faber (Anura, Hylidae) na enseada de Sítio Forte, Ilha Grande, Angra dos Reis, Brasil. Comunicata Scientiae 4(2):195-202.

Magnusson, W. E. \& Hero, J. M. 1991. Predation and the evolution of complex oviposition behavior in Amazonian rainforest frogs. Oecologia 86(3):310-318.

Martins, M. 1993a. Observations on nest dynamics and embryonic and larval development in the nest-building gladiator frog, Hyla faber. Amphibia-Reptilia 14(4):411-421.

1993b. Observations on the reproductive behavior of the smith frog, Hyla faber. Herpetological Journal 3:31-34.

Martins, M. \& HadDad, C. F. B. 1988. Vocalizations and reproductive behavior in the smith frog, Hyla faber Wied (Amphibia: Hylidae). Amphibia-Reptilia 9:49-60.

Martins, M.; Pombal JR., J. P. \& Haddad, C. F. B. 1998. Escalated aggressive behaviour and facultative parental care in the nest building gladiator frog, Hyla faber. Amphibia-Reptilia 19:65-73.

Martins, M.; Sazima, I. \& Egler, S. G. 1993. Predators of the nestbuilding gladiator frog, Hyla faber, in southeastern Brazil. AmphibiaReptilia 14(3):307-309.

Mitchell, N. J. \& Seymour, R. S. 2003. The effects of nest temperature, nest substrate, and clutch size on the oxygenation of embryos and larvae of the Australian Moss Frog, Bryobatrachus nimbus. Physiological and Biochemical Zoology 76:60-71.

Oliveira, J. M. \& Pillar, V. D. 2004. Vegetation dynamics on mosaics of Campos and Araucaria forest between 1974 and 1999 in Southern Brazil. Community Ecology 5(2):197-202.

PilLaR, V. D. 1999. The bootstrapped ordination re-examined. Journal of Vegetation Science 10(6):895-902.

2014. MULTIV: Multivariate Exploratory Analysis, Randomization Testing and Bootstrap Resampling. V3.15. Available at: $<$ http://ecoqua.ecologia.ufrgs.br/ecoqua/MULTIV. html>. Acessed on: 10 July 2014.

Pillar, V. D. \& OrlócI, L. 1996. On randomization testing in vegetation science: Multifactor comparisons of releve groups. Journal of Vegetation Science 7(4):585-592.

Refsnider, J. M. \& JAnZen, F. J. 2010. Putting eggs in one basket: ecological and evolutionary hypotheses for variation in ovipositionsite choice. Annual Review of Ecology, Evolution and Systematics 41:39-57.

RYan, M. J. 1980. Female male choice in a Neotropical Frog. Science 209(4455):523-525.

Sanabria, E. A. \& Quiroga, L. B. 2011. Facultative nesting in Rhinella spinulosa (Anura: Bufonidae): strategy to avoid dehydration of offspring. Belgian Journal of Zoology 141(2):85-89.

Seymour, R. S. 1999. Respiration of aquatic and terrestrial amphibian embryos. American Zoologist 39(2):261-270.

WeLLS, K. D. 2007. The ecology and behavior of amphibians. Chicago, The University of Chicago Press. $1400 \mathrm{p}$.

Zank, C.; Di-Bernardo, M.; Maneyro, R.; Colombo, P.; Fusinatto, L. A. \& Fonte, L. F. M. 2010. Spatial and temporal distribution of Pseudis minuta (Anura, Hylidae, Hylinae) and environmental variables related to its reproductive activity in Reserva Biológica do Lami, southern Brazil. Iheringia, Série Zoologia 100(2):145-150.

Zug, G. R.; Vitt, L. J. \& Caldwell, J. P. 2001. Herpetology: An introductory biology of amphibians and reptiles. 2ed. San Diego, Academic Press. 630p. 
Appendix 1. Matrix with all data collected in the field and factors used to run Anova and Manova analysis [nest area, nest area in $\mathrm{cm}^{2}$; nest depth: nest depth in $\mathrm{cm}$; in $\mathrm{t}^{\circ} \mathrm{C}$, water temperature inside nest $\left({ }^{\circ} \mathrm{C}\right)$. Habitat descriptors: Description, set of environmental variables measured in each plot; out $t^{\circ} \mathrm{C}$, water temperature $\left({ }^{\circ} \mathrm{C}\right)$ in the nest surrounding; dept, water depth $(\mathrm{cm})$; vege, total vegetation cover in each plot $(\%)$; heig, total vegetation height (cm); poac, total cover of Poaceae plants in each plot (\%); forb, total cover of forb plants in each plot (\%); cype, total cover of Cyperaceae plants in each plot (\%); junc, total cover of Juncaceae plants in each plot (\%); spha, total cover of Sphagnum sp. in each plot (\%); org, total cover of organic matter in suspension in each plot (\%); soil, soil resistance, measured as the depth of a stone-maded hole (cm); marg, plot distance from the pond margin $(\mathrm{cm})]$.

\begin{tabular}{|c|c|c|c|c|c|c|c|c|c|c|c|c|c|c|c|c|c|c|}
\hline \multirow[b]{2}{*}{$\begin{array}{l}\text { Sampling } \\
\text { unity }\end{array}$} & \multicolumn{3}{|c|}{$\begin{array}{l}\text { Anova and Manova } \\
\text { factors }\end{array}$} & \multicolumn{3}{|c|}{ Nest features } & \multicolumn{12}{|c|}{ Habitat predictors } \\
\hline & Pond & Plot & Block & $\begin{array}{l}\text { nest } \\
\text { area }\end{array}$ & $\begin{array}{r}\text { nest } \\
\text { depth }\end{array}$ & $\begin{array}{l}\text { in } \\
\mathrm{t}^{\circ} \mathrm{C}\end{array}$ & $\begin{array}{l}\text { out } \\
\mathrm{t}^{\circ} \mathrm{C}\end{array}$ & dept & vege & heig & poac & forb & cype & junc & spha & org & soil & marg \\
\hline nest 1 & 1 & 1 & 1 & 360 & 10 & 18,6 & 20,2 & 21 & 80 & 6 & 95 & 5 & 0 & 0 & 0 & 0 & 3,25 & 50 \\
\hline no nest 1 & 1 & 2 & 1 & 0 & 0 & 0 & 20,2 & 45 & 40 & 5,2 & 97 & 3 & 0 & 0 & 0 & 0 & 6,5 & 100 \\
\hline nest 2 & 1 & 1 & 2 & 418 & 4,5 & 18 & 20,1 & 15,5 & 95 & 13,5 & 80 & 10 & 0 & 10 & 0 & 0 & 9,25 & 275 \\
\hline no nest 2 & 1 & 2 & 2 & 0 & 0 & 0 & 20,5 & 42 & 35 & 6,2 & 100 & 0 & 0 & 0 & 0 & 0 & 12,5 & 210 \\
\hline nest 3 & 1 & 1 & 3 & 780 & 9 & 17,4 & 18,8 & 22 & 90 & 13 & 80 & 10 & 0 & 10 & 0 & 0 & 16 & 490 \\
\hline no nest 3 & 1 & 2 & 3 & 0 & 0 & 0 & 20,5 & 55 & 0 & 0 & 0 & 0 & 0 & 0 & 0 & 0 & 55 & 537 \\
\hline nest 4 & 1 & 1 & 4 & 357 & 6 & 18,6 & 18,2 & 5 & 90 & 11,8 & 75 & 5 & 20 & 0 & 0 & 0 & 12,25 & 1060 \\
\hline no nest 4 & 1 & 2 & 4 & 0 & 0 & 0 & 19,9 & 12 & 10 & 10 & 96 & 3 & 0 & 3 & 0 & 0 & 28 & 1160 \\
\hline nest 5 & 1 & 1 & 5 & 525 & 12 & 17,6 & 16,8 & 7 & 80 & 4,5 & 40 & 15 & 0 & 45 & 0 & 0 & 17 & 1350 \\
\hline no nest 5 & 1 & 2 & 5 & 0 & 0 & 0 & 19,6 & 20 & 95 & 30,8 & 7 & 8 & 0 & 85 & 0 & 0 & 28 & 1450 \\
\hline nest 6 & 1 & 1 & 6 & 588 & 12,5 & 17,2 & 19 & 8 & 95 & 12,1 & 85 & 0 & 0 & 15 & 0 & 0 & 27,25 & 1400 \\
\hline no nest 6 & 1 & 2 & 6 & 0 & 0 & 0 & 19,5 & 5 & 95 & 16,4 & 0 & 5 & 0 & 95 & 0 & 0 & 13 & 1500 \\
\hline nest 7 & 1 & 1 & 7 & 441 & 8 & 19,9 & 18,4 & 8 & 95 & 13 & 45 & 55 & 0 & 0 & 0 & 0 & 17,25 & 1700 \\
\hline no nest 7 & 1 & 2 & 7 & 0 & 0 & 0 & 19,6 & 11 & 95 & 3,4 & 0 & 3 & 0 & 97 & 0 & 0 & 7 & 1800 \\
\hline nest 8 & 1 & 1 & 8 & 378 & 9 & 21,1 & 19,6 & 9 & 95 & 11,2 & 30 & 68 & 2 & 0 & 0 & 0 & 12,25 & 2050 \\
\hline no nest 8 & 1 & 2 & 8 & 0 & 0 & 0 & 18,7 & 71 & 95 & 6,2 & 0 & 0 & 0 & 100 & 0 & 0 & 11,25 & 1950 \\
\hline nest 9 & 1 & 1 & 9 & 336 & 13 & 18,1 & 19,1 & 9,5 & 85 & 20,8 & 35 & 5 & 45 & 15 & 0 & 0 & 8 & 1450 \\
\hline no nest 9 & 1 & 2 & 9 & 0 & 0 & 0 & 17,4 & 2 & 50 & 8,6 & 100 & 0 & 0 & 0 & 0 & 0 & 27,5 & 1350 \\
\hline nest 10 & 1 & 1 & 10 & 390 & 10 & 20,5 & 18,8 & 11 & 65 & 11,8 & 55 & 5 & 40 & 0 & 0 & 0 & 17,5 & 470 \\
\hline no nest 10 & 1 & 2 & 10 & 0 & 0 & 0 & 18,5 & 16 & 55 & 50,4 & 25 & 25 & 25 & 25 & 0 & 0 & 17 & 650 \\
\hline nest 11 & 2 & 1 & 11 & 361 & 9 & 18,3 & 18,8 & 88 & 45 & 19,6 & 45 & 35 & 20 & 0 & 0 & 0 & 12,5 & 100 \\
\hline no nest 11 & 2 & 2 & 11 & 0 & 0 & 0 & 18,5 & 86 & 5 & 1,6 & 80 & 10 & 0 & 10 & 0 & 0 & 51,2 & 120 \\
\hline nest 12 & 2 & 1 & 12 & 493 & 14,5 & 17,5 & 18,7 & 24 & 75 & 39 & 30 & 15 & 50 & 0 & 0 & 5 & 17,75 & 0 \\
\hline no nest 12 & 2 & 2 & 12 & 0 & 0 & 0 & 17,8 & 88 & 20 & 3,9 & 0 & 3 & 7 & 0 & 0 & 90 & 91,8 & 150 \\
\hline nest 13 & 2 & 1 & 13 & 262,5 & 8 & 17,5 & 16,8 & 6 & 75 & 20,6 & 30 & 0 & 50 & 15 & 0 & 0 & 19,25 & 240 \\
\hline no nest 13 & 2 & 2 & 13 & 0 & 0 & 0 & 20,2 & 4 & 85 & 22 & 75 & 10 & 15 & 0 & 0 & 0 & 3 & 150 \\
\hline nest 14 & 2 & 1 & 14 & 650 & 11 & 25,4 & 19 & 48 & 75 & 10 & 35 & 0 & 5 & 0 & 60 & 0 & 17 & 120 \\
\hline no nest 14 & 2 & 2 & 14 & 0 & 0 & 0 & 19,2 & 45 & 3 & 2,8 & 30 & 10 & 30 & 0 & 0 & 30 & 85 & 220 \\
\hline nest 15 & 2 & 1 & 15 & 470 & 11 & 18,5 & 17,4 & 17 & 90 & 10 & 0 & 15 & 5 & 0 & 80 & 0 & 17,5 & 200 \\
\hline no nest 15 & 2 & 2 & 15 & 0 & 0 & 0 & 17,5 & 10 & 95 & 16,4 & 70 & 15 & 15 & 0 & 0 & 0 & 6 & 100 \\
\hline nest 16 & 2 & 1 & 16 & 483 & 11 & 21 & 20 & 31 & 70 & 5,6 & 10 & 10 & 35 & 0 & 20 & 25 & 4,5 & 112 \\
\hline no nest 16 & 2 & 2 & 16 & 0 & 0 & 0 & 19,9 & 43 & 30 & 5 & 50 & 0 & 0 & 0 & 45 & 5 & 43 & 270 \\
\hline nest 17 & 2 & 1 & 17 & 441 & 14 & 20,3 & 17,9 & 21 & 70 & 8,7 & 25 & 5 & 10 & 0 & 60 & 0 & 22,5 & 420 \\
\hline no nest 17 & 2 & 2 & 17 & 0 & 0 & 0 & 18,2 & 13 & 80 & 55,6 & 85 & 15 & 0 & 0 & 0 & 0 & 5,5 & 210 \\
\hline nest 18 & 2 & 1 & 18 & 483 & 8 & 20,5 & 21,1 & 51 & 80 & 17,6 & 50 & 5 & 45 & 0 & 0 & 0 & 10 & 300 \\
\hline no nest 18 & 2 & 2 & 18 & 0 & 0 & 0 & 20,5 & 62 & 30 & 0 & 0 & 0 & 1 & 0 & 0 & 30 & 62 & 180 \\
\hline
\end{tabular}

